\title{
PERBANDINGAN KONSTITUSIONAL : PENGATURAN IMPEACHMENT DI INDONESIA DAN ITALIA
}

\author{
Muhammad Zulhidayat \\ Fakultas Hukum Universitas Muhammadiyah Tangerang \\ Email : zulhidayat007@gmail.com
}

\begin{abstract}
Abstrak
Mekanisme pemberhentian Presiden dalam masa jabatan melalui impeachment process awalnya dikenal di dalam Hukum Tata Negara Amerika Serikat, lalu berkembang sehingga diikuti oleh negara-negara yang menganut sistem demokrasi, diataranya Indonesia dan Italia. impeachment sendiri dapat diartikan sebagai tuduhan atau dakwaan. Sehingga impeachment lebih menitikberatkan pada prosesnya dan tidak harus berakhir dengan berhenti atau turunnya Presiden atau pejabat tinggi negara tersebut dari jabatannya. Mekanisme ini dinilai sebagai wujud saling mengawasi satu sama lain antar lembaga eksekutif, legislatif dan yudikatif. Dalam jurnal ini rumusan masalah yang diangkat adalah bagaimanakah perbandingan mekanisme impeachment Presiden dan/atau Wakil Presiden antara sistem ketatanegaraan di Indonesia dan Italia ?, Penelitian dalam jurnal ini menggunakan metode pendekatan yang bersifat Perbandingan Hukum (comparative law). Simpulan dalam penelitian ini adalah Indonesia dan Italia sama-sama melibatkan DPR dan Mahkamah Konstitusi. Akan tetapi, secara mekanisme kedua negara mempunyai impeachment process yang berbeda. Saran dalam penelitian ini adalah Indonesia harus mengatur lebih jelas terkait syaratsyarat Presiden dan/atau wakil presiden bisa di-impeach. Hal ini dikarenakan dalam UUD Tahun 1945 Pasal 7A tidak menjelaskan terkait perbuatan tercela seperti apa sehingga menyebabkan Presiden dan/atau Wakil Presiden bisa dilakukan Impeachment Process.
\end{abstract}

Kata Kunci : Impeachment, Konstitusi, Presiden. 


\begin{abstract}
The mechanism of the President through the impeachment process originally known in the United States Constitutional, then developed by the countries which is considering the democracy system, including Indonesia and Italy. impeachment is interpreted as an accusation or indictment. So that the impeachment is more aimed at the process and does not have to end with the stop or decline of the President or high-ranking state official from his position. This mechanism is considered to be used to supervise each other, between executive, legislative and judicial institutions. In this journal the formulation of the problem is how is the comparison of the impeachment mechanism of the President and / or Vice President between constitutional systems in Indonesia and Italy?, Research in this journal uses a comparative law approach. Conclusions in this reasearch is Indonesia and Italy both involving the DPR and the Constitutional Court. However, the impeachment process is different. The suggestion in this reasearch is that Indonesia must regulate more clearly the conditions the President and / or vice president can impeach. because in the Constitution of the Indonesian Republic of article 7A doesn't explain what kind of disgraceful actions are related to causing the President and / or Vice President to do the Impeachment Process.
\end{abstract}

\title{
Keywords : Impeachment, Constitution, President.
}




\section{PENDAHULUAN}

Indonesia diidealkan dan dicita-citakan oleh the founding fathers sebagai suatu negara hukum ( Rechtstaat/The Rule Of law). UUD NRI Tahun 1945 Pasal 1 Ayat (3) menegaskan bahwa "Negara Indonesia adalah Negara Hukum. ${ }^{1}$ Indonesia bukanlah negara yang berdasarkan kekuasaan belaka (Machtsstaat). Dengan demikian, segala tindakan yang dilakukan oleh pemerintah harus berlandaskan peraturan perundang-undangan yang berlaku. Peraturan perundang-undangan tersebut harus mengatur perbuatan tersebut terlebih dulu atau mendahului perbuatan yang dilakukan (asas legalitas) ${ }^{2}$.

Sebagai negara hukum, Indonesia tentu harus mempunyai Konstitusi/UUD sebagai dasar dan asas dalam penyelenggaraan negara. Adanya konstitusi juga digunakan sebagai sebuah kontrol untuk penguasa agar tidak melakukan tindakan yang sewenang-wenang. Dilain sisi, konstitusi juga bisa dijadikan sebagai sebuah tameng/pelindung bagi rakyat terhadap kebijakan penguasa yang bersifat merugikan kepentingan rakyat. Sedemikian pentingnya Konstitusi, membuat setiap negara didunia harus mempunyai Konstitusi. Walaupun hingga saat ini, negara seperti Israel dan Inggris tidak mempunyai Konstitusi yang mereka kodifikasi, akan tetapi tetap saja ada aturan yang tidak dikodifikasi seperti putusan hakim yang dijadikan asas dalam penyelenggaran negara tersebut.

Dalam perkembangannya, Konstitusi terus mengalami perubahan dari masa ke masa, contoh sederhana kita bisa lihat di Indonesia. Pada awalnya, Indonesia menggunakan UUD 1945 sebagai konstitusi. Akan tetapi setelah 3 tahun

\footnotetext{
${ }^{1}$ Jimly Asshiddiqie, Menuju Negara Hukum yang Demokrasi, (Jakarta : Sekretariat Jenderal dan Kepnaiteraan Mahkamah Konstitusi, 2008), hal. 201

${ }^{2}$ Legalitas berasal dari kata dasar legal yang memiliki makna sesuatu yang berarti sah atau diperbolehkan, sehingga legalitas memiliki makna bahwa sesuatu yang diperbolehkan atau sesuatu yang menerangkan keadaan diperbolehkan atau sah. Asas legalitas dinamakan juga dengan kekuasaan undang-undang (de heerschappij van de wet), istilah asas legalitas dalam hukum pidana (nullum delictum sine praveia leg poenali) yang artinya adalah tidak ada hukuman tanpa undangundang.
} 
setelahnya, Indonesia merubah konstitusi dengan menggunakan UUD RIS pada Tahun 1949, tidak sampai satu tahun UUD RIS digunakan sebagai dasar penyelenggaraan negara, Indonesia kembali mengganti konstitusinya dengan menggunakan UUDS 1950. Konstitusi ini pun tidak berjalan lama, tepat pada Tahun 1959, Indonesia melalui dekrit presiden kembali merubah Konstitusinya dengan mengembalikan UUD NRI Tahun 1945 sebagai dasar fondasi bangsa ini.

Perubahan dan pergantian konstitusi tidak selesai sampai disitu, pada era reformasi desakan untuk memperbaharui konsitusi semakin menjadi sesuatu yang urgen. Perubahan UUD 1945 kembali dilakukan pada rentang waktu 1999 hingga 2002, total empat kali perubahan sudah dilakukan pada saat itu. Hal ini tidak terlepas dari tugas yang diemban negara dalam menyelenggarakan kesejahteraan umum, maka pembentukan berbagai peraturan termasuk Konstitusi di sebuah negara menjadi sangat penting. Sebagaimana yang kita ketahui bersama negara dewasa ini juga bertugas dalam mengurusi kesejahteraan rakyat baik di bidang hukum, sosial, politik, ekonomi, budaya, lingkungan hidup, serta pertahanan keamanan. Selaras dengan tugas diatas sehingga tugas negara dalam memperbaharui konstitusi atau peraturan pun tidak mungkin lagi dihindari. ${ }^{3}$

Dengan adanya perubahan konstitusi/amandemen yang terjadi pada UUD NRI Tahun 1945, ada banyak ketentuan yang telah mengalami perubahan, bahkan hampir meliputi seluruh aspek. UUD NRI Tahun 1945 sebagai dasar hukum tertinggi dalam sistem hukum Indonesia telah berubah dari yang awalnya UUD 1945 yang asli mencakup 71 butir ketentuan. Sekarang setelah mengalami empat kali perubahan butir ketentuan yang tercakup di dalamnya berjumlah 199 butir. Dan jika kita analisa lebih jauh kembali, maka hanya 25 butir ketentuan yang berasal dari naskah asli yang disahkan oleh PPKI pada tanggal 18 Agustus 1945. Hal ini menunjukan bahwa semakin tingginya keinginan masyarakat untuk membawa negara ini kearah yang lebih baik.

\footnotetext{
${ }^{3}$ Maria farida Indrati, Ilmu Perundang-undangan, ( Yogyakarta : Penerbit Kanisius , 2007), hal. 1 .
} 
Salah satu persoalan penting setelah terjadinya empat kali perubahan UUD Tahun 1945 adalah adanya ketentuan yang secara eksplisit mengatur terkait dengan Impeachment atau kita lebih mengenal dengan istilah pemakzulan/pemberhentian Presiden dan/atau Wakil Presiden dalam masa jabatannya. Impeachment terhadap Presiden dan/atau Wakil Pesiden dilakukan oleh Majelis Permusyawaratan Rakyat (MPR) atas usul Dewan Perwakilan Rakyat (DPR). ${ }^{4}$

Apabila kita melihat negara lain maka akan kita jumpai beberapa kali kasus impeachment, sebagai contoh adalah Amerika Serikat, negara yang menjadi kiblat negara demokrasi ini telah melakukan impeach terhadap presiden mereka sebanyak 2 (dua) kali, hal ini terjadi pada Presiden Andrew Johnson pada tahun 1868. Adapun yang menjadi alasan dilakukakannya impeachment adalah high crimes and misdemeanor yang pada saat itu diinterpretasikan sebagai melabrak aturan. Andrew Johnson pada saat itu dinilai telah melanggar sumpah jabatan sebagai seorang presiden karena memberhentikan Menteri Pertahanan Edwin M.Santon tanpa meminta persetujuan dari Senat. ${ }^{5}$

Selanjutnya, Presiden Amerika Serikat lainnya yakni Bill Clinton juga diimpeach. Hal dilakukan terkait skandalnya dengan pegawai Gedung Putih Monica Lewinsky. Dalam penyelidikan kasus itu, Clinton dituding berbohong dan menghalang-halangi penyelidikan dan menghambat kerja lembaga peradilan. Selain kedua presiden diatas, upaya impeachment juga pernah ingin dilakukan kepada Richard Nixon. Pasal yang dikenakan kepada Richard Nixon antara lain penyalahgunaan kekuasaan, penghinaan terhadap Kongres dan menghambat kerja peradilan. Seluruh tuduhan tersebut berkaitan erat dengan Skandal Watergate. Namun sebelum keputusan voting impeachment dilakukan, Richard Nixon pada saat itu memilih mengundurkan diri sebagai Presiden Amerika Serikat. ${ }^{6}$

Banyak pihak yang memahami bahwa impeachment merupakan turunnya, berhentinya atau dipecatnya Presiden atau pejabat tinggi dari jabatannya. Akan

\footnotetext{
${ }^{4}$ Mahkamah Konstitusi Republik Indonesia, Undang-Undang Dasar Negara Republik Indonesia Tahun 1945, ( Jakarta: Sekretariat Jendral MK RI, 2006), hal. 66-67

${ }^{5}$ Ezra Natalyin, Dua dari 45 Presiden AS Pernah Kena Impeachment, Siapa Saja?, https://www.viva.co.id/berita/dunia/916370-dua-dari-45-presiden-as-pernah-kena-impeachmentsiapa-saja, diakses pada tanggal 4 Juli 2019.

6 ibid
} 
tetapi, jika melihat secara penafsiran gramatikal maka arti impeachment sendiri dapat diartikan sebagai tuduhan atau dakwaan. Sehingga impeachment lebih menitikberatkan pada prosesnya dan tidak harus berakhir dengan berhenti atau turunnya Presiden atau pejabat tinggi negara tersebut dari jabatannya. Mekanisme ini dinilai sebagai wujud saling mengawasi satu sama lain antar lembaga eksekutif, legislatif dan yudikatif. Sehingga pertanggungjawaban setiap lembaga negara kepada rakyat akan jauh lebih transparan. Jika kita menilai lebih jauh, dengan adanya mekanisme impeachment ini akan membuat antar lembaga negara saling mengawasi hal ini tentu berguna untuk mengurangi penyalahgunaan wewenang (detournement) yang kiranya sering terjadi dewasa ini.

Selanjutnya, ketika kita membahas mengenai permasalahan impeachment ini, maka disetiap negara tentu mempunyai proses yang berbeda-beda. Hal ini biasanya diatur langsung dalam konstitusi sebuah negara. Namun secara umum, mekanisme impeachment akan melalui proses peradilan tata negara, dalam hal ini akan melibatkan lembaga yudikatif, baik itu lembaga Mahkamah Agung (Supreme Court) atau bisa juga Mahkamah Konstitusi (Constitutional Court). Jika sebuah negara memiliki 2 lembaga pemegang kekuasaan yudikatif yaitu Mahkamah Agung dan Mahkamah Konstitusi, maka kecenderungan negara tersebut akan melalui proses impeachment di Mahkamah Konstitusi. Akan tetapi, keterlibatan Mahkamah Konstitusi dalam proses impeachment tentu juga akan berbeda di masing-masing negara. Hal ini dipengaruhi oleh sistem pemerintahan yang digunakan/dianut oleh negara tersebut serta yang paling penting adalah kewenangan yang diberikan oleh Konstitusi sebuah negara kepada Mahkamah Konstitusi dalam proses impeachment.

Berdasarkan ulasan diatas, menarik kiranya jika kita membandingkan bagaimana mekanisme impeachment di Indonesia dengan negara lain. Oleh karena itu, dalam jurnal ini Penulis mengambil rumusan masalah yakni, Bagaimanakah perbandingan mekanisme impeachment Presiden dan/atau Wakil Presiden antara sistem ketatanegaraan di Indonesia dan Italia? 


\section{METODE PENELITIAN}

Agar penyusunan penulisan ini dapat terarah dan tidak menyimpang, maka harus dilakukan berdasarkan metode-metode tertentu. Hal ini disebabkan, suatu penelitian merupakan usaha untuk menemukan, mengembangkan dan menguji kebenaran suatu pengetahuan. Penelitian dalam jurnal ini menggunakan metode pendekatan yang bersifat Perbandingan Hukum (comparative law). Penggunaan metode perbandingan dalam Hukum Tata Negara sangat penting untuk dikembangkan, paling tidak ada dua hal yang bisa didapatkan dari metode perbandingan, pertama, dalam rangka mengembangkan teori Hukum Tata Negara yang bersifat umum, dan kedua, dalam rangka lebih mendalami dan mengembangkan studi Hukum Tata Negara Positif. Penulis memilih Italia karena ingin membandingkan proses impeachment negara yang menganut sistem Parlementer seperti Italia dengan Indonesia yang menganut sistem Presidensial. Spesifikasi penelitian dalam penulisan ini adalah bersifat deskriptif analitis. Tipologi Penelitian menggunakan tipologi preskriptif analitis. ${ }^{7}$ Adapun bahan hukum yang digunakan mencakup bahan-bahan hukum yang terdiri dari, UndangUndang Dasar Negara Republik Indonesia Tahun 1945, The Constitution of the Italian Republic, Undang-Undang Nomor 24 tahun 2003 tentang Mahkamah Konstitusi, Undang-undang Nomor 17 tahun 2014 Tentang Majelis Permusyawaratan Rakyat, Dewan Perwakilan Rakyat, Dewan Perwakilan Daerah dan Dewan Rakyat Daerah. Metode analisa yang digunakan dalam penelitian ini adalah bersifat kualitatif, yakni kebenaran data/premis akhir ditentukan oleh penelitinya sendiri. Bentuk hasil penelitian akan disajikan dalam bentuk preskriptifanalitis.

\section{HASIL PENELITIAN DAN ANALISIS}

a. Mekanisme Impeachment menurut sistem ketatanegaraan Indonesia

${ }^{7}$ Soerjono Soekanto dan Sri Mamudji, Penelitian Hukum Normatif (Jakarta : Raja Grafindo Persada, 2009), hal 13 
Pada perkembangan konsitusi di Indonesia, tidak ditemukan suatu pembahasan yang spesifik mengatur mengenai impeachment. Baik ketika UUD Tahun 1945 dirumuskan oleh Badan Penyelidik Usaha Persiapan Kemerdekaan (dokuritu zyunbi tyosa kai) maupun rapat-rapat Panitia Persiapan Kemerdekaan Indonesia. Akan tetapi, bukan berarti presiden tidak dapat dimintai pertanggungjawaban dalam menyelenggarakan penyelenggaran kekuasaan pemerintahan negara. Presiden akan tetap mempertanggung-jawabkan segala kebijakan kepada Majelis Permusyawaratan Rakyat.

Setelah perkembagan pasca reformasi, Indonesia telah melakukan empat kali amandemen terhadap UUD Tahun 1945, amandemen dilakukan sejak era 1999 hingga 2002. Perubahan tersebut juga mempertegas pembagian kekuasaan antar lembaga negara dengan sistem saling mengawasi dan saling mengimbangi (checks and balances). Dengan adanya keseimbangan atau check and balances yang khas antara Pemerintah dan DPR yang sama-sama kuat. DPR kuat karena tidak dapat dibubarkan oleh Pemerintah, sementara itu Pemerintah juga kuat karena tidak bisa dijatuhkan oleh DPR. Pola hubungan ini menjadi penting dalam demokrasi Pancasila. $^{8}$

Selanjutnya, ada beberapa konsekuensi akibat dari amandemen UUD Tahun 1945 diantaranya amandemen UUD Tahun 1945 mempunyai pengaruh terhadap kedudukan Presiden dan/atau Wakil Presiden di Indonesia. Pada Perubahan Ketiga UUD Tahun 1945, telah diintrodusir suatu norma baru, yakni mengenai mekanisme impeachment process atau pemberhentian presiden dan/atau wakil presiden dalam masa jabatannya. ${ }^{9}$ Pengaturan mengenai impeachment ini terdapat dalam Pasal 7A UUD NRI tahun 1945, yang menjelaskan bahwa : "Presiden dan/atau Wakil Presiden dapat diberhentikan dalam masa jabatannya oleh Majelis Permusyawaratan Rakyat atas usul Dewan Perwakilan Rakyat, baik apabila terbukti telah melakukan pelanggaran hukum berupa pengkhianatan terhadap negara, korupsi, penyuapan, tindak pidana berat lainnya, atau perbuatan tercela maupun

\footnotetext{
${ }^{8}$ Mahfud MD, Politik Hukum di Indonesia, ( Jakarta : Rajawali Press, 2014 ), hal. 39.

${ }^{9}$ I Gede Yusa, dkk, Hukum Tata Negara, ( Malang : Setara Press, 2016 ), hal. 11
} 
apabila terbukti tidak lagi memenuhi syarat sebagai Presiden dan/atau Wakil Presiden".

Selain telah diaturnya secara eksplisit pasal yang khusus mengatur mengenai impeachment. Dengan adanya Perubahan Ketiga UUD Tahun 1945 ini juga menyebabkan perubahan terhadap kewenangan MPR. Hal ini terjadi karena sebelum amandemen UUD NRI Tahun 1945, MPR bertugas memilih dan mengangkat Presiden/Wakil Presiden, berubah menjadi tugas yang lebih bersifat seremonial saja, sebagaimana dirumuskan dalam Pasal 3 ayat (2) UUD NRI Tahun 1945: "Majelis Permusyawaratan Rakyat melantik Presiden dan/atau Wakil Presiden", Ketentuan Pasal ini kemudian diikuti dengan rumusan yang memberi kewenangan untuk memberhentikan Presiden dan atau Wakil Presiden dalam masa Jabatannya sebagaimana yang tertuang dalam Pasal 3 ayat (3) UUD NRI Tahun 1945: "Majelis Permusyawaratan Rakyat hanya dapat memberhentikan Presiden dan/atau Wakil Presiden dalam masa jabatannya menurut Undang- Undang Dasar”.

Ketentuan inilah yang memberi dasar kepada MPR untuk melakukan impeachment. Kewenangan MPR berdasarkan Konstitusi diatas juga dapat dihubungkan dengan Pasal 7A, Pasal 7B dan Pasal 24C ayat (2) UUD NRI Tahun 1945 yang memberi dasar pengaturan mengenai cara pengajuan, mekanisme dan prosedur impeachment di Indonesia. Dari segi proses dan mekanismenya impeachment di Indonesia terbagi dalam dua jalur, jalur pertama dilakukan melalui proses politik dan jalur kedua melalui proses hukum. Dalam jalur proses politik, maka proses impeachment berawal dari adanya dugaan oleh DPR bahwa Presiden dan/atau Wakil Presiden telah melakukan pelanggaran sebagaimana ditentukan dalam Pasal 7A UUD NRI Tahun 1945.

Selanjutnya dalam proses hukum, mekanisme impeachment diatur dalam Pasal 7B UUD NRI Tahun 1945. Secara sederhananya, Proses impeachment dalam proses hukum dimulai ketika pendapat DPR diajukan ke Mahkamah Konstitusi untuk diperiksa, diadili, dan diputus. Peran dari Mahkamah Konstitusi dalam proses impeachment ini juga semakin menegaskan Indonesia menganut prinsip sebagai negara hukum. Hal ini dikarenakan Putusan Mahkamah Konstitusi merupakan 
putusan hukum yang didasarkan pada pertimbangan hukum dan tidak boleh ada intervensi terhadap 9 hakim Mahkamah Konstitusi dalam melaksanakan tugasnya. Kewenangan tersebut diberikan langsung oleh UUD NRI tahun 1945, sebagaimana dalam Pasal 24C Ayat (2) menjelaskan bahwa : "Mahkamah Konstitusi wajib memberikan putusan atas pendapat Dewan Perwakilan Rakyat mengenai dugaan pelanggaran oleh Presiden dan/atau Wakil Presiden menurut Undang- Undang Dasar."

Hasil dari Putusan Mahkamah Konstitusi ini akan menjadi rujukan/ acuan bagi DPR mengenai apakah usul pemberhentian Presiden dan/atau Wakil Presiden tersebut dilanjutkan atau dihentikan. Apabila dalam putusannya, Mahkamah Konstitusi membenarkan adanya pelanggaran oleh Presiden dan/atau Wakil Presiden maka selanjutnya DPR menyelenggarakan sidang paripurna untuk meneruskan usul pemberhentian Presiden dan/atau Wakil Presiden ke Majelis Permusyawaratan Rakyat.

Jika kita melihat kembali sejarah yang ada di Indonesia, Impeachment telah dilakukan sebanyak 2 (dua) kali, ${ }^{10}$ yakni terjadi pada Presiden Soekarno dan Presiden Abdurrahman Wahid. Akan tetapi, impeachment yang terjadi pada Abdurrahman Wahid alasannya juga masih belum dapat teruji kebenarannya secara konstitusional, hal ini dikarenakan sebagian anggota DPR baru menduga Presiden Abdurrahman Wahid terlibat dalam kasus Buloggate dan Bruneigate. Oleh karenanya, permasalahan ini masih sulit dibuktikan secara hukum kebenarannya.

\section{b. Mekanisme Impeachment menurut sistem ketatanegaraan Italia}

Pada masa lalu, didalam budaya dibeberapa adat, sistem sanksi hukum dibuat dalam bentuk yang sangat sederhana. Hanya ada dua cara dalam menyikapi penyimpangan kekuasaan, yaitu membiarkan atau dihukum mati. Seseorang yang

${ }^{10}$ Soimin, Impeachment Presiden dan Wakil Presiden di Indonesia, (Yogyakarta: UII Press, 2009). hal. 1. 
terus-menerus membuat masalah akan dilakukan konsultasi informal, maka selanjutnya akan ditombak dan dibuang. ${ }^{11}$

Sebagaimana yang telah disinggung diatas, seiring perkembangan zaman mekanisme impeachment mulai diperkenalkan dan dikenal di Konstitusi Amerika serikat pada Tahun 1787, pemakzulan melalui mekanisme impeachment ini juga diadopsi oleh negara Inggris akan tetapi belum mempunyai mekanisme yang baku. Jika kita melihat sejarah maka sidang impeachment terakhir di Inggris dilakukan terhadap Warren Hasting yang akhirnya memutuskan Hasting tidak bersalah.

Dalam Konstitusi di Italia, Presiden bisa di-impeach jika melakukan pengkhianatan tingkat tinggi terhadap negara dan serangan terhadap konstitusi atau melanggar konstitusi, hal ini dijelaskan dalam Pasal 90 konstitusi Italia :

The President of the Republic is not responsible for the acts performed in the exercise of his duties, except for high treason or plots against the Constitution. In such cases he is impeached by Parliament in joint session, with an absolute majority of its members.

Kedua pelanggaran diatas memang tidak dijelaskan secara eksplisit oleh konstitusi. Akan tetapi, pada tingkat umum pengkhianatan tingkat tinggi didefinisikan ketika Presiden Italia melanggar tugas kesetiaannya atau berkhianat kepada Republik, termasuk dalam menjalin hubungan dengan negara-negara asing. Sedangkan serangan terhadap konstitusi terjadi ketika Presiden Italia, berperilaku dengan cara tidak setia terhadap nilai-nilai konstitusi dan lembaga-lembaga konstitusional.

Pasal diatas sebenarnya sudah mengalami perubahan, perubahan dilakukan pada tahun 16 Januari 1989, sebelumnya dalam Pasal 90 teks asli kosntitusi Italia menjelaskan bahwa :

The President of the Council of Ministers and the Ministers are subject to impeachment by the Parliament in joint session of both Houses for crimes committed in the exercise of their duties.

\footnotetext{
${ }^{11}$ Hamdan Zoelva, Pemakzulan Presiden di Indonesia, ( Jakarta : Sinar Grafika, 2011 ), hal.
} 
Sementara itu, dalam proses impeachment di Italia memiliki kesamaan dengan Indonesia. Dalam konstitusi Italia juga menjelaskan bahwa yang berhak mengadili dan memutus kasus impeachment adalah Mahkamah Konstitusi. Pada awalnya impeachment terhadap presiden akan diproses oleh Parlemen. Selanjutnya setelah suara mayoritas dari parlemen memutuskan untuk me-impeach Presiden oleh mayoritas absolut dari anggotanya, maka proses selanjutkan akan diserahkan sepenuhnya ke Mahkamah Konstitusi untuk diadili. Hal ini dijelaskan dalam Pasal 134 konstitusi Italia, menjelaskan bahwa The Constitutional Court shall decide :..... Accusations made against the President of the Republic, according to the Constitution, sedangkan untuk mekanismenya diatur dalam Pasal 135 Konstitusi Italia, yang menjelaskan bahwa :

In proceedings to impeach the President of the Republic, in addition to the ordinary judges of the Court, there shall also be sixteen members chosen by lot from among a list of citizens having the qualification necessary for election to the Senate, which the Parliament prepares every nine years through election using the same procedures as thoseemployed in appointing ordinary judges.

Jika kita analisa terkait dengan impeachment di Italia, maka langkah pertama, setelah adanya permintaan resmi untuk dakwaan oleh parlemen, maka akan dilakukan pembentukan maksimal komisi 20 anggota. Pembentukan komisi ini dipilih dari anggota dewan. Komisi ini mengevaluasi tuduhan dan memutuskan apakah akan mengajukannya pertanyaan ke Parlemen dalam sesi bersama: dalam kasus ini, untuk melanjutkan, mayoritas absolut sudah cukup (50\% ditambah 1, atau 477 suara).

Setelah memutuskan untuk melanjutkan impeachment maka putusan tersebut menjadi milik Mahkamah Konstitusi. Dalam memutus permasalahan Impeachment, Mahkamah Konstitusi terdiri dari 15 hakim. Selanjutnya hakim tersebut bergabung dengan 16 anggota yang diambil secara undian dari daftar warga negara dengan persyaratan untuk kelayakan Senator. Berbeda dengan yang ada di Indonesia, Hakim Mahkamah Konstitusi di Italia dipilih setiap 9 tahun sekali. 
Pemilihan dilakukan dengan prosedur yang sama dengan penunjukan hakim konstitusi biasa. Dalam memutus impeachment di Mahkamah Konstitusi, maka Jaksa penuntut yang dipilih oleh Parlemen kemudian juga bergabung untuk mendukung tuduhan terhadap Presiden Italia. Dalam putusan Mahkamah Konstitusi di Italia, maka hanya akan ada dua hukuman yang diterima oleh Presiden Italia, yakni hukuman pemecatan atau pembebasan. Adapun putusan dari Mahkamah Konstitusi di Italia sama dengan Putusan Mahkamah Konstitusi di Indonesia yang bersifat final dan menganut prinsip erga omnes.

Jika kita sederhanakan proses impeachment di Italia, Kepala Negara/ Presiden di Italia diberikan kekebalan terhadap kejahatan umum yang dapat dituduhkan kepadanya, artinya Presiden Italia dapat diadili hanya karena pengkhianatan tingkat tinggi atau karena menyerang Konstitusi sebagaimana diatur dalam Pasal 90 Konstitusi Italia, ketika ada pelanggaran Piagam seperti mendistorsi karakterkarakter dan lain sebagainya. Maka proses impeachment terhadap presiden di Italia tidak diizinkan oleh konstitusi. Sementara itu, dalam proses imepachment di Italia, ada dua lembaga negara yang punya peranan penting dalam proses impeachment. Pertama, yakni Parlemen, dalam sidang bersama untuk proses impeachment parlemen memainkan peran penuntutan (setelah menetapkan prosedur yang dapat diterima), kedua, yakni Mahkamah Konstitusi, dalam hal ini Mahkamah Konstitusi diberi kewenangan untuk mengeluarkan hukuman, baik pembebasan atau pemecatan. $^{12}$

Jika kita melihat sejarah di Italia, sejauh ini di Italia belum ada Presiden Italia yang pernah didakwa berdasarkan Pasal 90 Konstitusi diatas. Walaupun di Italia ada kasus-kasus yang dilakukan oleh Presiden, akan tetapi kasus tersebut belum pernah diproses di Mahkamah Konstitusi. Kasus pertama adalah kasus yang terjadi pada Tahun 1964 terhadap Presiden Antonio Segni. Hal ini terjadi karena peran Segni sebagai Presiden dalam merencanakan kudeta ("Piano Solo") bersama dengan Jenderal De Lorenzo. Akan tetapi impeachment tidak dilakukan karena

12 Domenico Zurlo, Impeachment, che cos'è e come funziona in Italia. Ecco cosa dice l'articolo 90 della Costituzione, https://www.leggo.it/politica/news/impeachment_cos_e3761267.html, diakses pada tanggal 11 Juli 2019. 
Segni sakit, kemudian digantikan oleh presiden Senat Cesare Merzagora, beberapa bulan setelah itu Segni memilih mengundurkan diri dari Presiden Italia. ${ }^{13}$

Kasus kedua terjadi pada masa pemerintahan Presiden Giovanni Leone yang dituduh oleh PCI terkait dengan skandal penyuapan Lockheed. Akan tetapi, kasus tidak diproses oleh Mahkamah Konstitusi karena Leone memilih mengundurkan diri enam bulan sebelum diproses Mahkamah Konstitusi Italia. Kasus ketiga adalah kasus Presiden Francesco Cossiga yang terjadi pada 6 Desember 1991, PDS (partai di Italia) bersama-sama dengan pasukan oposisi lainnya mengajukan permintaan dakwaan kepada Parlemen dengan 29 dakwaan terhadap Cossiga. Akan tetapi Cossiga memutuskan untuk mengundurkan diri dua bulan sebelumnya.

Itulah kasus-kasus yang terjadi di Italia, akan tetapi tidak ada yang diputus oleh Mahkamah Konstitusi Italia karena Presiden memilih mundur. Akan tetapi, sebagaimana yang telah dipaparkan diatas, impeachment sendiri dapat diartikan sebagai tuduhan atau dakwaan. Sehingga impeachment lebih menitikberatkan pada prosesnya dan tidak harus berakhir dengan berhenti atau turunnya Presiden atau pejabat tinggi negara tersebut dari jabatannya

\section{PENUTUP}

\section{A. KESIMPULAN}

Berdasarkan analisis dalam penelitian ini maka dapat disimpulkan berbagai hal, seperti berikut:

a. Banyak pihak yang memahami bahwa impeachment merupakan turunnya, berhentinya atau dipecatnya Presiden atau pejabat tinggi dari jabatannya. Akan tetapi, jika melihat secara penafsiran gramatikal maka arti impeachment sendiri dapat diartikan sebagai tuduhan atau dakwaan. Sehingga impeachment lebih menitikberatkan pada prosesnya dan tidak harus berakhir dengan berhenti atau turunnya Presiden atau pejabat tinggi negara tersebut dari jabatannya. Dengan adanya mekanisme impeachment

${ }^{13}$ Raffaele Verderese, Ma l'impeachment contro Mattarella sarebbe stato poi percorribile?, https://www.agi.it/fact-checking/impeachment_mattarella_m5s_di_maio-3967626/news/2018-0530/, diakses pada tanggal 11 Juli 2019. 
ini akan membuat antar lembaga negara saling mengawasi hal ini tentu berguna untuk mengurangi penyalahgunaan wewenang (detournement) yang kiranya sering terjadi dewasa ini.

b. Dari segi proses dan mekanismenya impeachment di Indonesia terbagi dalam dua jalur, jalur pertama dilakukan melalui proses politik dan jalur kedua melalui proses hukum. Dalam jalur proses politik, maka proses impeachment berawal dari adanya dugaan oleh DPR bahwa Presiden dan/atau Wakil Presiden telah melakukan pelanggaran sebagaimana ditentukan dalam Pasal 7A UUD NRI Tahun 1945. Selanjutnya dalam proses hukum, mekanisme impeachment diatur dalam Pasal 7B UUD NRI Tahun 1945. Secara sederhananya, Proses impeachment dalam proses hukum dimulai ketika pendapat DPR diajukan ke Mahkamah Konstitusi untuk diperiksa, diadili, dan diputus. Hasil dari Putusan Mahkamah Konstitusi ini akan menjadi rujukan/ acuan bagi DPR mengenai apakah usul pemberhentian Presiden dan/atau Wakil Presiden tersebut dilanjutkan atau dihentikan.

c. Sementara itu, dalam proses impeachment di Italia memiliki kesamaan dengan Indonesia. Dalam konstitusi Italia juga menjelaskan bahwa yang berhak mengadili dan memutus kasus impeachment adalah Mahkamah Konstitusi. Pada awalnya impeachment terhadap presiden akan diproses oleh Parlemen. Selanjutnya setelah suara mayoritas dari parlemen memutuskan untuk me-impeach Presiden oleh mayoritas absolut dari anggotanya, maka proses selanjutkan akan diserahkan sepenuhnya ke Mahkamah Konstitusi untuk diadili. Dalam putusan Mahkamah Konstitusi di Italia, maka hanya akan ada dua hukuman yang diterima oleh Presiden Italia, yakni hukuman pemecatan atau pembebasan.

\section{B. SARAN}

Adapun saran yang penulis berikan dari hasil penelitian ini adalah sebagai berikut : 
a. Indonesia harus mengatur lebih jelas terkait syarat-syarat Presiden dan/atau wakil presiden bisa di-impeach. Hal ini dikarenakan dalam UUD NRI Tahun 1945 Pasal 7A menjelaskan salah satu syarat yang bisa dijadikan alasan seorang presiden dan/atau wakil presiden di-impeach adalah "melakukan perbuatan tercela", akan tetapi UUD NRI tahun 1945 tidak menjelaskan terkait secara jelas "perbuatan tercela" seperti apa yang dimaksud pasal tersebut sehingga menyebabkan Presiden dan/atau Wakil Presiden bisa dilakukan Impeachment Process.

b. Indonesia harus mengatur kembali mengenai Proses Pengajuan permintaan impeachment dari DPR kepada Mahkamah Konstitusi yang awalnya hanya dapat dilakukan dengan dukungan sekurang-kurangnya 2/3 dari jumlah anggota DPR yang hadir dalam sidang paripurna menjadi 50+1 sebagaimana diatur konstitusi di Italia. Hal ini dimaksudkan agar mekanisme impeachment yang diamanatkan oleh Konstitusi bisa terlaksana dengan baik sehingga Presiden akan lebih hati-hati dalam membuat kebijakan sehingga terlaksanalah check and balance antar lembaga eksekutif dan lembaga legislatif. 


\section{DAFTAR PUSTAKA}

\section{a. Buku}

Asshiddiqie Jimly, Menuju Negara Hukum yang Demokrasi.Jakarta : Sekretariat Jenderal dan Kepaniteraan Mahkamah Konstitusi. 2008.

Mahfud MD, Politik Hukum di Indonesia. Jakarta : Rajawali Press. 2014.

Mahkamah Konstitusi Republik Indonesia. Undang-Undang Dasar Negara Republik Indonesia Tahun 1945. Jakarta: Sekretariat Jendral MK RI. 2006.

Maria farida Indrati, Ilmu Perundang-undangan, Yogyakarta : Penerbit Kanisius , 2007.

Soekanto, Soerjono dan Sri Mamudji. Penelitian Hukum Normatif. Jakarta : Raja Grafindo Persada. 2009.

Soimin, Impeachment Presiden dan Wakil Presiden di Indonesia. Yogyakarta: UII Press, 2009.

Yusa, I Gede, dkk. Hukum Tata Negara. Malang : Setara Press. 2016.

Zoelva, Hamdan, Pemakzulan Presiden di Indonesia, Jakarta : Sinar Grafika, 2011.

\section{b. Peraturan Perundang-Undangan}

Constitution of the Italian Republic.

Indonesia, Undang-Undang Dasar Negara Republik Indonesia Tahun 1945.

Indonesia, Undang-undang Tentang Mahkamah Konstitusi, UU No. 23 Tahun 2004, LN. No 98 tahun 2003.

Indonesia, Undang-undang tentang MD3, UU No. 17 Tahun 2014, LN. No 182 Tahun 2014.

\section{c. Internet}


Natalyin, Ezra, Dua dari 45 Presiden AS Pernah Kena Impeachment, Siapa Saja? , https://www.viva.co.id/berita/dunia/916370-dua-dari-45-presiden-aspernah-kena-impeachment-siapa-saja, diakses pada tanggal 4 Juli 2019.

Verderese, Raffaele, Ma l'impeachment contro Mattarella sarebbe stato poi percorribile?, https://www.agi.it/factchecking/impeachment_mattarella_m5s_di_maio-3967626/news/2018-05-30/ ， diakses pada tanggal 11 Juli 2019.

Zurlo, Domenico, Impeachment, che cos'è e come funziona in Italia. Ecco cosa dice l'articolo 90 della Costituzione, https://www.leggo.it/politica/news/impeachment_cos_e-3761267.html , diakses pada tanggal 11 Juli 2019. 